\title{
An Analysis of the Path of College Students' Ideological and Political Education in the Context of Network and Big Data
}

\author{
Huiming Li \\ Harbin University of Commerce, Harbin Heilongjiang, 150028, China
}

Key words: Network, Large data age, College students, Ideological and political education path.

\begin{abstract}
With the continuous development of science and technology in China, information technology has pushed large data into new development field. In this context, all areas of society are gradually covered by network and large data, people's way of life and way of thinking also subtle changes in the change. In the concentration of higher education in colleges and universities, the development of large network of data is in-depth penetration of which, to the teaching work has brought great convenience, but at the same time there are some drawbacks. As the ideological and political education personnel in colleges and universities, we should fully understand the advantages and disadvantages of this transformation form, and avoid the disadvantages and actively explore the effective path of ideological and political education of college students.
\end{abstract}

\section{Introduction}

With the development and coverage of information technology and Internet technology in various fields, the current industry in various fields of our society has entered the data age with the development of science and technology. The concept of data in the subversion of the traditional "small data" meaning, in the form of large data to change people's way of life and the way the world get along. In this context, the ideological ideas and ways of thinking of college students have been profoundly affected, which brings convenience to the ideological and political education of college students at the same time there are some drawbacks.

\section{The Connotation of Networked Large Data and Its Connection with College Students' Ideological and Political Education}

\section{The connotation of large network data}

Network and large data are closely linked, the concept of the earliest in the last century 80's proposed, the development so far, the academic community on the large data and the relationship between the two networks is not very clear definition ${ }^{[1]}$. According to the British scholar Victor Meyer in the "Big Data Age" in a book to elaborate: large data is an unprecedented way, through the analysis of massive data, access to products and services, the greatest value and profound insights ${ }^{[2]}$. I will be described as: large data not only has the advantage of large capacity, it is able to rely on a huge capacity for the analysis and integration of massive data from the data in the extraction of great value to guide the current social practice.

\section{The Connection between College Students' Ideological and Political Education and Big Data}

First of all, in the background of network and large data, the sample of ideological and political education of college students is more comprehensive and rich. There are two kinds of research objects of contemporary college students' ideological and political education, which are the main objects, and these two levels refer to the students' ideological and political learning subjects are not randomly 
selected and the students' ideological and political education object data is not extracted. Network and large data in the auxiliary learning, college students ideological and political education staff no longer to the traditional small data extraction of teaching content, but by integrating all the large data to analyze the problem, so this background is the sample of all the data content The In the past, most of the methods of research on the subject are literature, observation, interview, questionnaire and so on. The form of these traditional learning methods cannot let the educators fully grasp the progress of the study and the improvement of the students. The analysis of learning and thought, to a large extent to ensure that students feedback dynamic information is more realistic and reliable, but also help educators more timely and accurate grasp of students' ideological trends and behavior trends, greatly improving the quality of teaching and research. Secondly, it further improves the correlation between ideological and political education and data information of college students. As the students on the network records can be stored in the form of data, and the ideological and behavioral trends of students' access to information possible. Many of the numerous data behind the hidden ideological activities of the important content of the past, the traditional teaching, the teacher is easy to show the students out of the real and chaotic errors of data information misleading, large data network era, large data system The analysis of their own will allow educators to clearly explore more students thinking and educational content of the link between the content, but also from the overall processing of data found in the process of data dissemination of the regularity, in order to obtain more traditional Teaching cannot grasp the ideological and behavioral characteristics of the students, but also help teachers to teach students according to their aptitude, good ideological and political education work ${ }^{[3]}$. Moreover, large data can also ensure that all students ideological and political education integration of the content. For the ideological and political education work of college students, the specific content is the most important, the process of education as much as possible to the content of data to ensure that the integration of content and data information in order to be more clearly structured to be reflected, and network The core of large data is to quantify all the information. Including the text of the data, such as ideological and political education of college students through the literal data to explain the existence of college students in the various ideas, to speculate on the reasons to grasp the ideological situation of students; also includes the orientation of data, that is, specific positioning services, The impact of college students living WeChat, microblogging and QQ and other social software, through its predictive behavior; then there is communication data, change the way teachers and students between the exchange, help through the network to carry out emotional exchange, Educators on real - time psychological counseling and education management.

\section{An Analysis of the Advantages and Disadvantages of Network and Big Data on College Students' Ideological and Political Education}

\section{The Influence of Network and Big Data on College Students' Ideological and Political Education}

First of all, large data to further promote the ideological and political education of the new development. At present, the education of college students should be accompanied by the development of the times, but many changes in the content of the content of the tutorial, the face of opportunities are also easy to fall into some of the cutting-edge new hot problems, not standing on a new height The Development of the Subject of Ideological and Political Education. Large data technology to help the subject of teaching to promote the extension of new ideas and the application of new methods to ensure that students of ideological and political education disciplines have more scientific methods, and with large data samples of students on all-round analysis, from a single analysis To the overall targeted study. Secondly, the big data for college students' ideological and political education practice provides a new way. China's ideological and political education of college students from the beginning of the embryonic stage has undergone several years of development, and has been in innovation and reform, and gradually formed a mature system, but still subject to a lot of traditional education model restrictions, there are many links show the original Of the teaching form, 
the performance of low technology content, the effect of ideological communication is not satisfactory. Big data as a new tool for students' ideological and political education practice can be used by educators to visualize their use, to analyze and analyze the principles and views of ideological and political education, to improve the credibility of political education, but also to focus on college students To a hot thing, and thus calculate the probability of predicting students' ideological and behavior development ${ }^{[4]}$. Moreover, large data can also be integrated with the ideological and political education of college students, the formation of new forms of teaching. In the process of gradually adapting to the development of large data, applied to the ideological and political teaching classroom, it is to create a new form of curriculum, constantly updated teaching philosophy. The application of large data technology, which combines a variety of disciplines of knowledge, in addition to the basic educational object of ideological and political professional, there are basic computer knowledge, methodology skills and social science knowledge. Teachers must be clear that the process of large data generation and ideological and political learning should be synchronized development, the process of learning itself is the transmission and reconstruction of information, so teachers use large data and network environment teaching, cannot just play its role in theory Stage, but also take the initiative to participate in the sharing of large data, so that students take the initiative to get information, integration of information, and truly become a tool for ideological and political learning to help students improve learning efficiency. In addition, the network and large data in the teaching of the application, but also for the educators to build a new and efficient teaching platform, enrich the educators to master the teaching resources, subtle changes in educators thinking. From the perspective of college students, it is to broaden the ideological and political vision, rich learning resources, students will undoubtedly play a great role in promoting learning.

\section{The Negative Influence of Network and Big Data on College Students' Ideological and Political Education}

Network and large data, after all, is a relatively new thing, in the teaching work for its benefits at the same time also accompanied by a lot of drawbacks, mainly reflected in three aspects. First of all, large data on the environment, the ideological and political education of college students to cultivate the environment will be more complex, multiple factors in the study of the infiltration of ideas, a lot of information on the network penetration, are one by one to show its complexity. And joy is also changing, once there is no timely control, it may lead to education in trouble, it is difficult to control. Secondly, the application of network and large data may also give the exclusive characteristics of ideological and political education, that is, dictatorship. Because the dynamic changes in large data to keep its daily growth in the expansion, but which contains the content is uneven and disorderly, in the forecast once a little careless, it will lead to education bias, or even The wrong conclusion. There is also the field of ideological and political education, after all, with the natural sciences, the latter to rely on a large number of experimental data quantitative analysis to accurate results to ensure that the teaching of information science, while the former allows students to have a unique free thinking, Of the data method to evaluate the individual's thinking, which gives education to add a lot of difficulty [5]. Moreover, the problem of technical work on education, such as the widespread distribution of large data, will inevitably increase the difficulty of data collection, and its diversification of the characteristics of infinite growth trends and data storage has brought a lot of pressure, and these data After processing and analysis to get the results, although it has the ability to integrate, but combined with the ideological and political education of the actual integration process, the need for educators to take their own. The adverse impact on the students more is to guide the difficulty of grasping, in addition to including large data in-depth application of the students after the construction of ethical knowledge problems, the impact of ideological and political concepts, but also to fall into the plight of professional and technical personnel. 


\section{Network of Ideological and Political Education of College Students under the Background of Network and Big Data}

\section{Establish and improve the corresponding large data regulations to protect the ideological and political education in colleges and universities}

As early as the end of 2015 the second World Internet Conference, President Xi Jinping on the promotion of the global Internet governance system, the topic of the speech delivered a speech. It can be seen from the national level, to ensure that large data in the collection and use of standardization, we must establish and improve the corresponding laws and regulations, clear and transparent use of administrative supervision of illegal acts of control. In the ideological and political education in colleges and universities, educators can set up a professional large data monitoring organization, for students' ideological and political education work from the data on the real-time supervision, standardize the use of data. From the school side, college students should be in the school within the relevant requirements and regulations in order to carry out ideological and political learning activities, the school should take more large data laws and regulations lectures for college students to provide appropriate educational activities of the standard system Guarantee.

\section{Establish a large data education awareness, change the traditional mode of thinking in the past}

Due to the short period of development of large data, it is very important for college students to use large data technology in ideological and political education to study. There is still a lot of awareness and consciousness. Therefore, it is very important to establish a large data education and learning consciousness. The First of all, the large size of large data so that educators are often only concerned about a small amount of data analysis results, not from the macro to grasp, so the education of all the consciousness must be established, and require students to learn data collection to do all-round collection, From the missing information mining useful data again. Second, to guide students from the large data complex chaos in the handling of the accuracy, and actively accept the different fresh information, and good from the diversification of students in the interpretation of their ideas and found that students exist. Finally, it is clear that the link between things to determine the relevance, which is the use of large data technology, the most core link, we must get the attention of educators.

\section{Give full play to the value and advantages of large data, custom personalized ideological and political education}

Teachers from the network and large data to collect a wealth of knowledge, combined with student feedback and performance, in order to develop personalized teaching programs, which are built on the basis of feedback and interaction. Therefore, under the background of large data teaching, teachers should actively use the network as the media to record the ideological and political theoretical knowledge into short micro video, and provide new teaching forms for the current college students' classroom learning. The teacher's teaching process, should also be aware of the importance of improving their own teaching methods, such as the teaching process online platform how to pay attention to students learning dynamic, with the platform how to implement the monitoring of student learning progress, line how statistics and feedback Students repeat the problem of video learning, and collect these data to analyze the degree of interest of students, more targeted integration of materials to help students find their own efficient learning methods.

\section{Conclusion}

In short, in the context of network and large data age, ideological and political education in colleges and universities must continue to innovate new teaching forms and efficient teaching methods, tap the advantages of using large data and network, create efficient teaching platform, with advanced technology Analyzes and solves the problems in the current ideological and political education work in colleges and universities, further organizes, filters and analyzes the data, forms a more targeted 
teaching program, and comprehensively improves the ideological and political level of college students.

\section{Acknowledgement}

Topic: Innovation of Ideological and Political Education in the Big Data Age (16KSD01).

\section{References}

[1] Liu Fengming, Ai Tiantian.. On the Innovation of College Students' Ideological and Political Education in the Context of "Micro - era", Journal of Xinyang Normal University (Philosophy and Social Sciences),2016,36(5):15-17.

[2] Wang Hongming, Chen Ruisan. On the Problems and Countermeasures of College Students' Ideological and Political Education in the Background of Big Data, Journal of Shenyang Jianzhu University (Social Science Edition)2016,18(1):76-79.

[3] Lin Zhida.The Path of Improving the Timeliness of Ideological and Political Education of College Students in the Era of Big Data, Journal of Hubei University of Economics (Humanities and Social Sciences), 2016,13(8):156-157.

[4] Qi Qige.On the Ideological and Political Education of College Students in the Background of Big Data, Journal of Social Science of Jiamusi University,2015,33(2):89-90.

[5] Sun Kaipeng.A Study on the Path of College Students' Ideological and Political Education in the Context of Network and Big Data, Education and Teaching Forum,2016,8(52):184-186. 